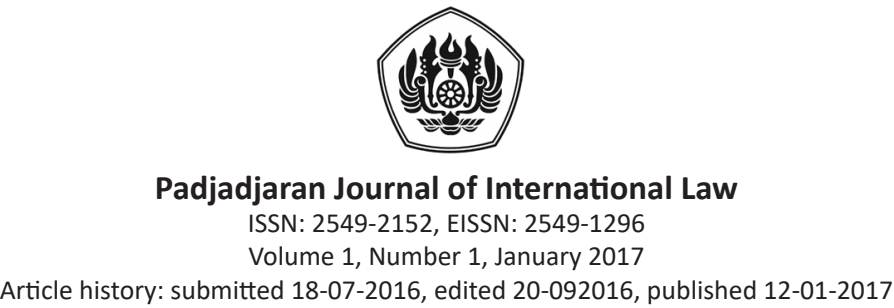

\title{
The Implementation of Article 47 Geneva Convention I to the Military (An Overview of Challenges within the Indonesian Armed Forces) \\ Fadillah Agus*
}

\begin{abstract}
The preferable implementation of article 47 of the First Geneva Convention 1949 is conducting activities in the format of military training and exercises rather than seminars. The contents, methodology as well as the instructor should be in accordance with military operations that will be encountered by the soldiers. "do what you have trained and train what you will do". The implementation of article $47 \mathrm{GCI}$ is related to article 82 and 87 AP I. Furthermore, within Tentara Nasional Indonesia (TNI) it is related with the formation of "the professional soldier" as enshrined in Article 2 section (4) of the Law No. 34 of 2004 of TNI. In addition to the increased awareness, some additional achievements related to operational and training aspects were also achieved in the period of 1998 - 2015. These include the issuance of Technical Guidance on the Implementation of international humanitarian law and human rights into the Training, the three standing ROEs and the TNI Commander decree on Prohibition of Torture. These all doctrinal impact are resulting from the dissemination program that may have influence on the betterment of the TNI operations in the future. However, some further improvements are required, among others, to improve the skills of the concerned officers to draft appropriate ROEs and to complement the legal unit with an operational law / international humanitarian law section. Moreover, the challenge for Indonesia in the future is to improve its enforcement mechanisms i.e. to enhance the military justice system to be more reliable and independent in line with the spirit of article $49 \mathrm{GC} \mathrm{I}$.
\end{abstract}

Keywords: international humanitarian law, armed conflict, military academy, dissemination program, laws of war.

\section{Implementasi Pasal 47 Konvensi Jenewa I di Bidang Militer (Tinjauan Tantangan-Tantangan di Dalam Tentara Negara Indonesia)}

\begin{abstract}
Abstrak
Pelaksanaan Pasal 47 dalam Konvensi Genewa Pertama 1949 adalah melaksanakan aktivitas dalam format aktivitas pelatihan dan militer dibandingkan dengan melakukan seminar. Isi dari pelatihan, metodologi dan instruktur harus sesuai dengan operasi militer yang dihadapi oleh seorang prajurit, "lakukanlah apa yang telah dilatihkan kepadamu dan latihlahlah apa yang akan kamu lakukan". Pelaksanaan pasal 47 Konvensi Genewa Pertama 1949 berkaitan dengan Pasal

\footnotetext{
* Dr. Fadillah Agus, S.H., M.H., is the honorary Lecturer at the Faculty of Law of Padjadjaran University and the Indonesia Defense University on the subject of IHL. The paper reflects the personal opinion of the Author and does not intended to reflect the opinion of any institution.
} 
82 dan 87 dari Konvensi yang sama. Lebih lanjut lagi, dalam Tentara Nasional Indonesia (TNI), berkaitan dengan pembentukan "prajurit profesional" seperti yang disampaikan dalam Pasal 2 ayat (4) Undang-undang No. 34 tahun 2004 mengenai TNI. Dalam rangka untuk meningkatkan kewaspadaan, beberapa capaian tambahan berkenaan dengan aspek operasional dan pelatihan juga dicapai dalam periode 1998-2015. Hal ini termasuk mengeluarkan Panduan Teknis mengenai Implementasi Hukum Humaniter Internasional dan HAM dalam pelatihan, dan tiga pilar ROEs dan keputusan Panglima TNI tentang Larangan Penyiksaan. Semua doktrin ini lahir dari dampak diseminasi dalam program pelatihan untuk melahirkan prajurit TNI yang lebih baik dimasa yang akan datang. Meskipun demikian, sejumlah peningkatan terhadap pengetahuan mengenai hukum humaniter telah tumbuh dikalangan prajutit TNI. Tantangan selanjutnya adalah mendorong peningkatan mekanisme pentaatan, misalnya mendorong sistem pengadilan militer untuk lebih indeoenden dan dapat diandalkan sejalan dengan semangat Pasal 49 Konvensi Genewa Pertama 1949.

Kata kunci: hukum humaniter, konflik bersenjata, akademi militer, program diseminasi, hukum perang.

\section{A. Introduction}

Indonesia has ratified the Geneva Conventions of 1949 (hereinafter the Geneva conventions or $\mathrm{GC})^{1}$ by enacted the Law No. 59 of 1958 without any reservation. All the total of $429^{2}$ articles of the four Geneva Conventions of 1949 are certainly very important to respect and implement by any country particularly in time of armed conflict. Those articles are materialized the humanitarian principles that have to be respected in a very delicate situation i.e. armed conflict. Indeed, the urgency to respect and implement the GC is even more important nowadays as the casualities of armed conflicts are getting worst.

Therefore the very first article of the GC stipulates that the High Contracting Parties undertake to respect and to ensure respect for the present Convention in all circumstances. ${ }^{3}$ In all circumstances means the obligation should be implemented both in peacetime and in the situation of armed conflict.

Although the GC is mainly governing armed conflict and consequently most of the articles are to be implemented in time of armed conflict, the Conventions also need to be implemented in peace time: for instance the part about dissemination of the Conventions. Article 47 of the (I) GC stipulates ${ }^{4}$ :

The High Contracting Parties undertake, in time of peace as in time of war, to disseminate the text of the present Convention as widely as possible in their respective countries, and, in particular, to include the study thereof in their programs of military and, if possible,

\footnotetext{
1 The Geneva Conventions 1949 consists of four Conventions. Convention (I) for the Amelioration of the Condition of the Wounded and Sick in Armed Forces in the Field. Convention (II) for the Amelioration of the Condition of Wounded, Sick and Shipwrecked Members of Armed Forces at Sea. Convention (III) relative to the Treatment of Prisoners of War.Convention (IV) relative to the Protection of Civilian Persons in Time of War.

2 Excluded the Annexes.

3 Article 1 Geneva Conventions. The Article 1 is one of the common Articles to the Geneva Conventions, meaning the said Articles can be found in all Geneva Conventions 1949 (I, II, III and IV); the formulation of the said Articles are the same, sometimes the numbers are the same in each Convention; I, II, III and IV.

${ }^{4}$ Article 47 is also common articles. The same rule can be found in article 46 GC II, 127 GC III, and 144 GC IV.
} 
The Implementation of Article 47 Geneva Convention I to the Military

civil instruction, so that the principles thereof may become known to the entire population, in particular to the armed fighting forces, the medical personnel and the chaplains.

This paper discusses the implementation of the above mentioned article within the Indonesian Armed Forces (TNI) in the period from 1998 to 2015. Some achievements have been made by the TNI, however, there is still room for improvement.

\section{B. Dissemination to the Military and Civilian}

The obligation to disseminate covers both the military and civilians. However, taking into account the nature of the conventions, priority should be given to the military. The objective of Article $47 \mathrm{GCl}$ is the provisions of the Convention and the principles to be incorporated into the military education programs, especially among the armed fighting forces, ${ }^{5}$ the medical personnel and the chaplains.

Why is military more important than the civilians in this regard? It is because it would positively impact to the military operation which comply to the GC and international humanitarian law (IHL). The latter will be impacted to good behavior of combat of the soldiers in the battle field. The knowledge of law is essential to the application of the conventions as one of the worst enemies of the $\mathrm{GC}$ is ignorance. ${ }^{6}$
The obligation to disseminate knowledge is not novel. Article 1 of Hague Convention IV on Respecting the Laws and Customs of War on Land of 1907 stipulates that the Contracting Powers shall issue instructions to their armed land forceswhich shall be in conformity with the Regulations respecting the laws and customs of war on land, annexed to the present Convention.

In Indonesia the obligation to disseminate to the GC to civilians is implemented, among others, by the international humanitarian law $(\mathrm{IHL})^{7}$ teaching to the students of the Faculty of Law particularly those majoring in (public) international law. At some Faculty of Law IHL is a compulsory subject for the international law students. In addition, IHL study centers are established at some Faculties of Law. Such study centers complement the teaching of IHL for the student as well as being a forum for the lecturers to deepen their knowledge about IHL. ${ }^{8}$ Students from other universities benefit from the study centers for their research project and their final papers. ${ }^{9}$

Starting a few years ago the subject of $\mathrm{IHL}$ is also taught at some Faculty of Political Science to students majoring on international relations. ${ }^{10}$ Perhaps in the near future the subject of IHL will also be taught at the Faculty of Medicine. The latter is necessary for Indonesia as all military doctors are alumna of Faculties of Medicine. In addition, one lesson learnt from

\footnotetext{
${ }^{5}$ Armed fighting forces cover the regular forces (belonging to the government) and the irregular forces or the dissident armed forces. In Columbia and Sri Lanka, for example, GC was also dissemnated to irregular forces.

${ }^{6}$ Jean S. Pictet et.al., Commentary I Geneva Convention, International Committee of the Red Cross, Geneva, 1952 , p. 348.

${ }^{7}$ Also known as the laws of war or the law of armed conflict. The Indonesian Red Cross Society ("PMI") name it as "Hukum Perikemanusiaan Internasional" (the Law of international humanity).

${ }^{8}$ Faculty of Law of Trisakti University was a pioneer in the establishing IHL study centers in Indonesia. Other IHL study centersare found at Syiah Kuala University, Banda Aceh and Sam Ratulangi University, Manado North Sulawesi.

${ }^{9}$ In particular between 1997 up to around 2003 the Trisakti IHL Study Centre ruling as the main reference sources for the study of IHL in Indonesia as it was at this centerthe referencematerials were available.

${ }^{10}$ ICRC's Delegation to Jakarta initiated the dissemination of IHL at Faculties of Political Science.
} 
the non-international armed conflict occurring in Aceh was that IHL and GC should be well understood by both military and civilian doctors and paramedics.

To implement the obligation under Article 47 GC I TNI has incorporated the subject of IHL into the military training and education programs at all levels; from the lowest up to the highest level. The number of class hours, teaching materials and methods IHL given at each level of education and training is different one to another depending on the needs at each level of education respectively.

\section{IHL Teaching at the Military Academy}

Military academy is one of the most strategic institution for any country to prepare the future nation's high command. Almost all the commander in chiefs and generals are the alumna of military academy. Nevertheless, the teaching of IHL at the Indonesia military academy was far behind compare to other subjects.

IHL teaching at the military academy has been significantly improved after 1992 . In 1990 a research team of the Law Faculty of Trisakti University led by the late Prof. GPH. Haryomataram, SH. Brig.Gen (ret.) conducted research on IHL teaching. ${ }^{11}$ The team examined the teaching on $\mathrm{IHL}$ at the higher education institutions i.e. the Military Academy and the Law Faculties. The objective of the research was to compare the teaching of IHL at the Faculty of Law and at the Military Academy.

The research conducted at some Law Faculties and the Indonesian Armed Forces Academy (AKABRI at the time). In 1990 AKABRI consisted of the Military Academy (Army) in Magelang, the Air Force Academy in Yogyakarta, the Naval Academy in Surabaya, and the Police Academy in Semarang. Until 1999 the branches of the Indonesian Armed Forces (ABRI) were the Army, Navy, Air Force and Police. ${ }^{12}$

The research team carried out an in-depth assessment on IHL knowledge of the students and cadets. Guided interview containing same questions was conducted towards the respondents both from the Military Academies and the Law Faculties. In addition, the interview was also conducted to the instructors as well as the lecturers. Furthermore, the syllabus, teaching materials and the references at the library were assessed.

The first conclusion of the research was that the level of understanding on IHL of the students at the Law Faculties were better than the cadets at the Military Academies (Army, Navy, Air Force and Police). Secondly, that the quality of the teaching of IHL at the Faculty of Law was better than at the Military Academies.

Prof Haryomataram became somewhat surprised when the research team reported to him about the conclusions mentioned above. This was understandable as he was a former Brigadier General and also the instructor of IHL at the Army's Military Academy in Magelang. It was difficult for him to believe that the understanding on IHL of the AKABRI's cadet was lower than that of the civilian law students. In other words, how could it be that the understanding of the laws of war in the military was lower than among civilians. However, eventually, he could understand this after the research team explained about

\footnotetext{
${ }^{11}$ The members of the research team were Endar Pulungan, S.H., IsmiWinarni, SH., Listyowati Sumanto, S.H., Fadillah Agus, S.H.

${ }^{12}$ From 1999 the Police separated from ABRI to become a civilian police force.
} 
The Implementation of Article 47 Geneva Convention I to the Military

the methodology of the research i.e. guided interview with the same questions to all respondents; cadets and students.

The same happened to the second conclusion. Prof Haryomataram, finally, understood that the quality of teaching on $\mathrm{IHL}$ at the Military Academieswas lower than at the Law Faculties after the research team explained to him that the text book ("diktat") used by the IHL instructors in 1990 was the book written by Prof. Haryo mataram in the 1970s. ${ }^{13}$ Moreover, the research team found that IHL was taught at the very first three months of education for the cadets with total 6 teaching hours including the exam. ${ }^{14}$

The team then presented the research to the leader of AKABRI at the ABRI HQ in Cilangkap, East Jakarta, The team was welcomed by Brig. Gen. Ade Picaulima, Deputy Commander of the General Commander of AKABRI accompanied by his staff. The research team presented in detail the research problems, methodology, data and information collected from the research as well as the conclusions and recommendations.

The leader of AKABRI well accepted the results of the research and followed it up accordingly. Around 2000 the author had seen a significant improvement of $\mathrm{IHL}$ teaching at the Army Military Academy, Magelang. The contents taught, the reference books and materials available at the library, the numbers of class hours given to the cadets as well as the quality of the instructors were very much improved compare with the situation in $1990 .^{15}$

In addition, at the same time, the research on the national implementation of GC in Indonesia jointly conducted by the IHL center of Syiah Kuala University, Banda Aceh and the IHL center of Sam Ratulangi University, Manado. The said research, among others, concluded that the IHL experts within TNI were getting better and their expertise was useful for the dissemination program as well as to be used as the military legal adviser. ${ }^{16}$

\section{Dissemination Program Started at the Legal Directorate}

In 1998 the International Comittee of the Red Cross (ICRC) welcomed by the Indonesian Army to conduct the dissemination program and the leader of the Indonesian Army agreed to the dissemination program plan accordingly. ${ }^{17}$ This shows that the policy of Army Leader is in line with the ratification of Geneva conventions by Indonesia.

The directive given by the leader of the Army was that the dissemination program should carried out jointly by the ICRC and the

\footnotetext{
${ }^{13}$ The indicators which led to these conclusions were the curriculum, substances to be taught, total class hours, references materials available at the library and the knowledge of the instructors.

${ }^{14}$ The first three months of education focusing on physics and body building of the cadets. The IHL class became a "sleeping class" as it was taught in the afternoon after the cadets got a heavy physical exercise.

${ }^{15}$ As the legal adviser of the ICRC Jakarta at that time the author had the opportunity to visit the Military Academy, Magelang, meet with the Head of Department and the IHL instructors and was able conducted a short assessment on the IHL teaching.

${ }^{16}$ IHL Center of Syiah Kuala University, Banda Aceh and Sam Ratulangi University, Manado, North Sulawesi, Research on the National Implementation on IHL, 2001, pages 233-234.

${ }^{17}$ The Chief of Staff, General Endriartono Sutarto, is agreed to the program. The concern of General Sutarto towards the legal aspects of the military operation shown, among others, when he wrote an article which concluded that the illegal order is not to be executed, Kompas, June 20, 2001page 4. The Assistant Operation to the Chief of Staff, Maj.Gen. Kiki Sjahnakri was very supportive to the program as he was supported even pushing more operational officers to attend the dissemination session.
} 
Legal Directorate of the Army. The late Brig. Gen.PLT. Sihombing, S.H., LL.M. served as the Director of the Legal Directorate. He played a significant role in the dissemination of $\mathrm{IHL}$ and GC to the members of TNI and in particular to the Army. ${ }^{18}$

Why through the Legal Directorate? The Article 82 of the Additional Protocoll of 1977 $(\mathrm{API})^{19}$ stipulates:

The High Contracting Parties at all times, and the Parties to the conflict in time of armed conflict, shall ensure that legal advisers are available, when necessary, to advise military commanders at the appropriate level on the application of the Conventions and this Protocol and on the appropriate instruction to be given to the armed forces on this subject.

The Commentary to the Additional Protocols 1977 states that the legal adviser could be selected either from the military or civilians. ${ }^{20}$ There are advantages and disadvantages to both alternatives. The advantages of those selected from the military, among others, is that they have a military training which enabling the persons concerned to evaluate situations from a tactical or strategic as well as from a technical point of view. ${ }^{21}$ While the advantage of the civilian lawyers is that they are already specialists in the law of armed conflict. ${ }^{22}$ However, under the existing conditions, most likely the legal advisers within TNI are military or legal officer.

The role of the legal officer is essential. The main task of the legal officer is to advise the military commander in time of armed conflict. Moreover, the legal adviser may be called upon to give legal opinion towards the military operations both during the planning of operations and while the military operations is on going. ${ }^{23}$

Moreover, in time of peace, the legal adviser is essential for the education and training of the IHL to the members of the armed forces at any level. All IHL instructors within the education and training units of TNI, from the lowest up to the highest level, are legal officers. For example in the Army, the IHL instructors at the private and NCO school are the legal officers of each territorial military command (Kodam). ${ }^{24}$ Within the command structure of the Kodam there is a Legal unit (Kumdam) headed by a Colonel, and the commander of the Kodam is a two star General. Furthermore, at the Joint Staff and Command College, the IHL instructors are the legal officers from the legal dept. of TNI $\mathrm{HQ}$ or from each of the services respectively.

\footnotetext{
${ }^{18}$ After completing his duty as the Legal Director of the Army then he was assigned as the Head of Legal Bureau of the Defense Ministry. At the Ministry of Defense he continued the dissemination of IHL and Geneva Conventions in a more strategic level i.e. initiated the Decree of the Defense Minister on IHL in 2002

${ }_{19}$ Protocol Additional to the Geneva Conventions of 12 August 1949, and relating to the Protection of Victims of International Armed Conflicts (Protocol I), 8 June 1977.

${ }^{20}$ Yves Sandoz et.al., Commentary on the Additional Protocols of 8 June 1977 to the Geneva Conventions of 12 August 1949 (hereinafter as the Commenrary), ICRC - Martinus Nijhoff Publishers, Geneva 1987, page. 955, para 3363.

${ }^{21} \mathrm{lbid}$, para. 3364.

${ }^{22}$ Ibid., page 956, para. 3365.

${ }^{23}$ For example the legal adviser may advise the commander on targeting and the choice of arms for a planned military operation, or the legal adviser may give the legal opinion on the issue of collateral damages during an ongoing military operation.

${ }^{24}$ There are thirteen Kodams in Indonesia .Each Kodam covering one or several provinces. The Indonesian Army has a decentralized recruitment system for the privates and NCOs. Their training is also run by the mother regiment of Kodam ("ResimenlndukKodam or Rindam). IHL is taught both at the private and t NCO school.
} 
The Implementation of Article 47 Geneva Convention I to the Military

Given the importance role of the legal adviser particularly in time of armed conflict, once appointed, they need to be integrated into the staff structure but also have direct access to the commander whenever they deem it necessary. ${ }^{25}$ In time of armed conflict, the legal adviser should always be available to the commander together with operational and intelligence assistant. ${ }^{26}$

The above mentioned factors led the leader of the Army to decide that the dissemination on IHL should begin with the legal directorate. The late Brig. Gen. Sihombing said that it was necessary to equip the legal officers with an appropriate knowledge on IHL and $\mathrm{GC}$ in order for them to be able to execute their tasks properly in their respective units.

Qualified legal advisers are required for the successful completion of military operations. The military operation is considered a success when it achieved the military goals without any, or at least with minimum, violation of law. In such military operation the commander should be accompanied by a qualified legal adviser who will advise him in commanding the operation included in the planning phase, so the commander will make decisions that are in line with IHL. These means that the violation of law is to be prevented prior to the military operation executed. Consequently the violation of law can be minimized or even an operation with zero violations could be accomplished.

The principle that the instructions given by the military commander or the head of state should be in accordance with the laws of war have been applied at least since the issuance of the Lieber Code in 1863. The Lieber Code is the first codification on the laws of war. It was prepared during the American Civil War by Prof. Francis Lieber of Columbia College in New York who got tasked by General Halleck and the instruction was issued by President Lincoln as Army Order 100 during the civil war in the USA. The content of the Lieber's Code was complete and comprehensive as it was drafted by a Professor who had a comprehensive and in-depth understanding on the laws of war and military law.

Taking into consideration to the importance and the need for qualified legal advisers mentioned above, the participants of the first seminar and workshop ("penataran") on IHL jointly organized by the Legal Directorate of the Army and the ICRC was the senior legal officers i.e. the Head of the Legal Unit of Regional Military Command (Kakumdam) from all over Indonesia. The session was also attended by the Head of the Legal Unit of the Main Army Command of TNI. ${ }^{27}$ In addition, the senior legal officers from the Navy and Air Force, as well as from the military justice (prosecutors and the judges), attended the "penataran".

Due to the operational situations faced by the Army, the contents of dissemination program not only covered the IHL and Geneva conventions (included the Additional Protocols) but also human rights. The knowledge and understanding of the human rights of the soldiers are needed as military operations conducted by the Indonesian Army are required

\footnotetext{
${ }^{25}$ Terry D. Gill and Dieter Fleck (eds.), The Handbook of the International Law of Military Operations, Oxford University Press, 2011, p. 551.

${ }^{26}$ Brigiader Sihombing uttered this during the preparation meeting of the dissemination program at the Legal Directorate of Indonesian Army.

${ }^{27}$ The Main Army Command ("KotamaDarat") of TNI is KOSTRAD (Army Reserve Command) and KOPASSUS (Army Special Force).
} 
to respect human rights. ${ }^{28}$

To visualize situations where violations of $\mathrm{IHL}$ and $\mathrm{HR}$ are likely to occur, the author together with the Indonesian Army officers, have developed simulations or field exercises. ${ }^{29}$ The scenarios include situations both from international and non-international armed conflict: and examples both of proper and improper, or law abiding and unlawful, behaviors are acted out by "actor-soldiers". In the field, directly after the tableaus; have been played by the "actor-soldiers," the participants in the trainings discuss the scenarios they just have observed and comment on irregularities and misbehavior they have identified. Also instances of proper behavior are identified. ${ }^{30}$

In addition to the legal officers having comprehensiveness knowledge of the law of armed conflict, the understanding of officers in other branches, in particular the operational and intelligence units is also important. Therefore, to equip such officers with appropriate knowledge of $\mathrm{IHL}$ and human rights is needed and their attendance in the "penataran" is therefore essential.

A major challenge faced by the instructors of the dissemination program in the beginning was the hesitance and negative perception of $\mathrm{IHL}$ and human rights among the officers. Not only the operational and intelligence officers hesitant, but also some legal officers were suspicious even cynical towards the whole idea that military activity should be subject to law.
They were in the opinion that IHL and human rights would hamper the military operation so that the goals of the military mission would never been achieved if the soldiers would have to fight in accordance with IHL rules and human rights. $^{31}$

A frequent complaint expressed by them was that when war crimes were committed by soldiers from developed countries the international community would be silent. They also frequently complained about the enforcement mechanisms, both nationally and internationally, which did not seem to be effective in addressing war crimes. ${ }^{32}$

However, as time passed, this hesitance and negative perception slowly faded. At the same time more operational and intelligence officers attended the "penataran". Their participation was influential to the quality of the program as during the sessions discussions was discussed about real cases that they had been involved. Such discussions made it clear to everybody that the law of armed conflict is not only law in book but also the law in action. ${ }^{33}$

In addition to the trainings conducted in Jakarta, the dissemination program jointly conducted by the Legal Directorate and ICRC also ran courses at several "Kodams". At the beginning priority was given to "Kodams" covering conflict prone areas. ${ }^{34}$ Latter the program ran in other "Kodams" aimed to increase the awareness and respect of IHL and human rights in any "Kodam".

\footnotetext{
${ }^{28}$ For example, the operation at Central Sulawesi, Moluccas, North Moluccas and Papua.

${ }^{29}$ In this regard, the role of Maj. Ahmad Fadilah, S.H., M.H. is very essential.

${ }^{30}$ Sometimes in order to give a real life effects, the simulation use the blank bullets and controlled explosives.

${ }^{31}$ One of participant to the "penataran" mentioned that IHL like a blindfold put on a boxer while he is fighting against his opponent. The blindfolded boxer will never win the fight.

${ }^{32}$ Questions, among others, regarding the invasion to Irak, Abu Ghraib case, Guantanamo case and cases involving Israel appeared frequently in all dissemination session.

${ }^{33}$ The Chatham House rules are applied when real cases are discussed during the trainings.

${ }^{34}$ Priority given to the "Kodams" located in the prone area, such as Aceh, Sulawesi, Moluccas and Papua.
} 
The Implementation of Article 47 Geneva Convention I to the Military

Article 82 of AP I stipulates that legal advisers should be available, when necessary, to advise military commanders at the appropriate level. This article is flexible as its uses the wording "when necessary" and "at the appropriate level". Therefore, the implementation of this article will vary from one country to another depending on the particular situation in respective country. ${ }^{35}$

The wording of "at appropriate level" means that it is the discretion of each high contracting party to decide at what command level they will assign legal advisers. Within the structure of the combat units of the Indonesian Army, the lowest commander that is equipped with a legal adviser is the Division commander. For example, the Army Reserve Command (KOSTRAD) commanded by a Lieutenant General is equipped with a legal office headed by a Colonel. While each division of KOSTRAD is equipped with a legal officer with the rank of Major. ${ }^{36}$ The Brigade commanders of KOSTRAD are not equipped with legal officers. ${ }^{37}$ Whereas the Army Special Forces (KOPASSUS), which is commanded by a two star General, has a legal office headed by aLt.Col. ${ }^{38}$

The posting of legal officers to the territorial commands is different from the combat units. As mentioned before within the "Kodam" structure there is a Legal Office ("Kumdam") headed by a Colonel. Under the "Kodam" there are a number of Military Command Resorts ("Korems") where each "Korem" covering several Districts. The "Korem" is commanded by a Colonel who is equipped with a small legal unit headed by a Major assisted by one Lieutenant and one sergeant. Further down, under the "Korem" there are several District Military Commands ("Kodim"). Each "Kodim" covering one district and commanded by a Lt. Col. who is not equipped with any legal officer.

Although the provision of legal advisers is only found in the API which apply to international armed conflict sand is not regulated in Additional Protocol II which apply to non-international armed conflict, states practice shows that the obligation to have available legal advisers to the commander also apply to the situation of non-international armed conflict. The United States for instance, although until now the US is yet to ratify Additional Protocols I and II but US has implemented these provisions and make extensive use of legal advisor. ${ }^{39}$ Indonesia also has not ratified yet the Additional Protocols I and II but has implemented the legal adviser provisions in the non-international armed conflict in Aceh.

\section{E. The Positive impacts of Dissemination Program}

One of the results of the intensive and extensive dissemination program has been that the awareness about IHL and human rights of the Indonesian Army has increased significantly. The Army applies a policy where they assign an ad hoc legal adviser attached to Battalions that

\footnotetext{
${ }^{35}$ See the rule 141 and States practice at Jen-Marie Henckaerts and Louise Doswald-Beck, Customary International Humanitarian Law, Cambridge University Press, 2005, Vol I and II.

${ }^{36}$ There are two divisions of KOSTRAD. Division 1 based in Cilodong, West Java and Division 2 based in Singosari, East Java.

${ }^{37}$ With the exception of Group 3 of Division I that equipped with a legal officer as its based in Kariango, South Sulawesi, is far from the Division HQ in Cilodong, West Java.

${ }^{38}$ KOPASSUS consisted of three groups and one anti-terror detachment. None of them equipped with Legal Officer.

39 Jean-Marie Heckaerts and Louise Doswald-Beck, loc.cit. The explanation in the previous paragraph shows that Indonesia also applies the rules on legal advisors even though Indonesia has not ratified the Additional Protocols 1977.
} 
are deployed to operations. ${ }^{40}$ Although on the organizational map of personnel and equipment ("table organisasi dan peralatan or TOP") of a Battalion that legal units or legal officers are not included but the Army Leader has leapfrogged these advances even though the "TOP" has not changed yet. ${ }^{41}$

Another indication of the increasing awareness is the issuance of the Guidance Book for the Soldiers in the Implementation of Human Rights or the human rights pocket book in 2000 by the Chief of Staff of the Army. The pocket book is distributed to soldiers at all level. ${ }^{42}$ The Army has not only distributed the book but also conducted a program to disseminate the pocket book to all units of the Army complemented with dissemination sessions jointly organized by the Legal Directorate and the ICRC.

Moreover, the practice to include a legal annex in the operational order became common within the Army units. Nowadays, almost all operational orders are issued with a legal annex, whereas prior to 2000 legal annexes were not commonly used in the Indonesian Army. ${ }^{43}$

A significant indication that the dissemination programs had a positive impact on the operations can be seen during the military operation conducted in Aceh in the period from 2002 to 2005. In 2002 the government of Indonesia decided to launch a full military operation to cope the Acehnese insurgency Free Aceh Movement ("GAM"). Military emergency rule was introduced and an Operational Command ("Komando Operasi or Koops") was established in Aceh while the Emergency Military Provincial Authority was taking over the responsibilities of the civilian Governor.

"Koops" was commanded by a two star General who commanded a reinforced division supported by the Navy and the Air Force. The command structure of the "Koops" was equipped with a permanent Legal Task Force ("Satuan Tugas Hukum or Satgaskum") headed by a Colonel that served as the legal adviser to the "Koops" commander. ${ }^{44}$ The "Satgaskum" was tasked, among others, to conduct assessment together with intelligence staff whenever there was armed contact between TNI and GAM that caused damages in particular when such contact caused death either of TNI members, GAM or civilians.

Furthermore, all soldiers deployed in Aceh were equipped with a pocket card that, among other things, contained descriptions of the application of basic principles on IHL. In addition, the TNI HQ applied a policy of providing IHL briefings to combat units deployed in Aceh. These briefings were held at the naval base just prior to the soldiers were dispatched to their respective posts. ${ }^{45}$

\footnotetext{
${ }^{40} \mathrm{Ad}$ hoc assignment means the legal officer will go back to his legal unit after the operation is accomplished and the concerned Battalion returns back to their home base.

${ }^{41}$ Brig.Gen. Arief Siregar, the Director of Legal Directorate who replaced Brig. Gen. Sihombing, told the author that the policy undertaken by the Army Leader was because of the operational and tactical considerations so the Battalion commander in the operation area needed to be accompanied by the legal officer.

${ }^{42}$ The book was accessible at the Indonesian Army's website.

${ }^{43}$ Within the operational order structure of the Indonesian Army the legal annex is placed under Annex $\mathrm{G}$ or $\mathrm{H}$.

${ }^{44}$ A permanent "Satgaskum" which is structured within the operation command had never existed before.

${ }^{45}$ The aim of the final briefing is to strengthen the IHL and human rights message to the soldiers just before they were deployed to the battle field. Usually it was organized at the hall or in the field of naval base where the unit had landed, either at Belawan Medan, Malahayati Banda Aceh or Krueng Guekueh Lhokseumawe.
} 
The Implementation of Article 47 Geneva Convention I to the Military

Besides the impact on the operation mentioned above, the dissemination also impacted on training. A lot more $\mathrm{IHL}$ and human rights were provided at pre-deployment training. ${ }^{46}$ Moreover, some tactics, both individual and at unit level, had to be modified in order to fit the requirements of $\mathrm{IHL}$ and human rights. ${ }^{47}$

One important pillar with regard to $\mathrm{IHL}$ and $H R$ dissemination was the issuance of the Technical Guidance Book for the Application of $\mathrm{IHL}$ and Human Rights in Training ("Buku Petunjuk Teknik Penerapan Hukum Humaniter dan HAM Dalam Latihan Penyelenggaraan/ Bujuknik Garlat HHI dan HAM") issued by the Training and Education Command of the Army ("Kodiklat $A D$ ") in July 2003. ${ }^{48}$ This technical guidance book is part of the training doctrine of the Indonesian Army. The content of the book is made so that it is applicative and easy to implement by the different units in their training programs at different levels and among different combat and support units. ${ }^{49}$ Interestingly, even though Indonesia has not ratified yet the Additional Protocols 1977 some of the rules from the AP 1977 were referenced to in at the guidance book.

Another notable impact was the Minister of Defense's Decree number 2 of 2002. The decree stipulates that IHL, Geneva conventions, international customary law and human rights applies to the state's defense efforts. The decree stipulates that this will be regulated further by Commander in Chief of TNI. ${ }^{50}$

Last, but not least, in 2010 the Commander in Chief of TNI issued a Commander's directive ${ }^{51}$ which prohibits the use of torture by TNI members. Indonesia ratified the Convention against Torture in 1998 but has yet to integrate the convention into national legislation. ${ }^{52}$ The TNI Commander's directive is an important and interesting breakthrough on the implementation of the Convention against Torture even though this directive can only be enforced internally within TNI.

\section{F. Operational Approach on IHL Training}

The ultimate objective of article $47 \mathrm{GC} I$ is the $\mathrm{IHL}$ and the principles of the $\mathrm{GC}$ is implemented in any military operation and so the unnecessary causalities of the armed conflict can be minimized. Some of the most influential actors that can contribute to achieve these objectives are the commanders, operational and intelligence officers and, last but not least, the soldiers in the field. Therefore the more the commanding, operational and intelligence officers have attended dissemination sessions

${ }^{46}$ Pre-deployment training is a training required for a unit prior to their deployment. For example a Battalion required a three months pre-deployment training for a $6-9$ months operation. The aim of the training is to enhance the military tactic and skills of the soldiers.

${ }^{47}$ For example the individual tactic on checking of the dead body or the unit tactic on searching and cordon of the house.

${ }^{48}$ The issuance of this book was initiated by Brig. Gen. Bambang Darmono, then the Director of Training at "Kodiklat", who later became the Commander of "Koops" in Aceh and then later again became the Commander of "Kodiklat".

${ }^{49}$ For example, the technical guidance given can be applied for a squad up to battalion level of training of the operation, intelligence or logistic branches, even for the fire support unit. The book drafted by a team consisted of the Indonesian Army officers where the author was the only civilian being the member of the drafting team.

${ }^{50}$ The decree was initiated by the late Brig. Gen. Sihombing, the Head of Legal Bureau of the Ministry of Defense.

${ }^{51}$ Peraturan Panglima TNI tentang Penentangan Terhadap Penyiksaandan Perlakuan Lain yang Kejam Dalam Penegakan Hukum di Lingkungan TNI (PERPANG/73/IX/2010).

${ }^{52}$ One of the recommendation of the Universal Periodical Review convened by the UN Human Rights Council that has not been implemented by Indonesia so far is to enact national legislation on it as so far the torture neither included in the criminal code nor in other national legislation. 
the more should the military operation be conducted in line with the rules.

In 2005, FRR Law Office ${ }^{53}$ in cooperation with the Army and the Norwegian Center for Human Rights (NCHR) organized a seminar on IHL in non-international armed conflict (NIAC). The topic NIAC was being chosen as this is the most likely type of armed conflict to occur in the country. The seminar lasted for two days and was attended by the Operational and Intelligence Assistant of "Kodams". During the seminar military and legal aspects of NIAC were elaborated on. The seminar contributed towards a common understanding among the influential officers of the "Kodam", i.e. Operational and Intelligence assistants across the country about the importance; as well as the self-interest of TNI to comply with IHL and respect human rights in the situation of NIAC.

From $2005 \mathrm{u}$ to 2015 FRR in cooperation with the Army Legal Directorate and further with TNI HQ, i.e. the Legal Department and the Operational Staff conducted dissemination program. The program was funded by the Norwegian Center for Human Rights, University of Oslo, which also contributed with experts, both civilian and military, to the program..$^{54}$ The program focused on the combat units of the Army as well as some Battalions under the command structure of the "Kodam". 55

The nomenclature used for the IHL dissemination program has been changed from seminar and workshops ("penataran") to training ("latihan"). The reason for this was that in order to achieve better compliance with IHL and human rights by the soldiers, training rather than seminars and workshops was essential. Also because the real objective that the trainings should contribute to was to integrate IHL and human rights into "the muscles and bones" of the soldiers rather than merely "stick it in their brains". Moreover, a prominent training doctrine for soldiers in any country of the world is "do what you train and train what you do". So the training is more suitable then seminars and workshops of the aim is behavioral changes.

A session on counter insurgency strategy (COIN) and tactics related to $\mathrm{IHL}$ was also included into the training program. COIN and $\mathrm{IHL}$ should be seen as connected since the main objective of a counter insurgency operation is to win the hearts and minds of the people. This can partly be gained by applying $\mathrm{IHL}$ and respecting human rights in such operations. The case study on counter insurgency was developed in order to underpin the usefulness of IHL and to stimulate two way communication. ${ }^{56}$

\footnotetext{
${ }^{53}$ FRR (Fadillah Rivai Rizki) Law Office is a private Law Firm. In addition to provide legal services like other Law firms, litigation and non-litigation, the Firm also runs a non-profit program, i.e. capacity building program on IHL and human rights within TNI. The program has been conducted in cooperation with TNI and the Norwegian Center of Human Rights, funded by the Norwegian government and partly by the Canadian and Australian government. FRR run the program parallel and in coordination with the ICRC in order to avoid overlapping and duplication.

${ }^{54}$ The program was an implementation of Bilateral Dialogue on Human Rights between Indonesia and Norway. In 2013 and 2014 the program conducted international training in cooperation with the International Institute of Humanitarian Law, San Remo, Italy, attended by officers from several Asian countries.

${ }^{55}$ The program was able conducted IHL and Human Rights training at Infantry Battalions in conflict prone areas, such as Aceh, Poso (Central Sulawesi), Moluccas and North Moluccas. In addition, the program covered all Infantry Battalions in Papua and West Papua. Moreover, the IHL training was regularly and continuously conducted at the Army Special Forces ("Kopassus") from 2007 up to 2015 where members of Norwegian Army's Special Forces were also part of the instructor teams.

${ }^{56}$ The sessions were led by Norwegian Army officer who had experience from counter insurgency operations in Afghanistan. Theparticipant officers shared their experiences which opened up for constructive two ways discussions.
} 
The Implementation of Article 47 Geneva Convention I to the Military

The inclusion of the counter insurgency perspective is essential for the Indonesia context in particular related the military operation in Aceh. The situation in Aceh qualified as a noninternational armed conflict where the TNI was fighting against the armed wing of the Free Aceh Movement Forces (in bahasa Indonesia: "GAMBersenjata"). The question on applying IHL and the Geneva Convention in Aceh was controversial. On one side was the view that the IHL applies while the other side claimed that IHL did not apply. The debate around whether the situation in Aceh qualified as a non-international armed conflict or merely as internal disturbances and tension. ${ }^{57}$ However, such academic debate was avoided, as much possible, in the training session. The message passed on in the training was that regardless of the qualification of the situation the principles of humanity had to be respected and implemented in any TNI operation.

The instructors consisted of military and civilian experts both Indonesian nationals and the foreigners. ${ }^{58}$ The advantage of the foreigner instructors, both civilian and military, among others, was that they could share perspectives from a different point of view so the participants could compare how these questions are solved in other countries. Importantly, the foreigner officers were able to speak with the participants in the same language i.e. "the soldier's language".
One of important element in any current military operation is ROEs (Rules of Engagement). Within ROEs is included the political, legal and military considerations for the concerned military operation. ROEs are the commander instrument in commanding his unit. Well-made ROEs would lead the concerned unit to achieve their mission and at the same time contribute to prevent or minimize both unnecessary suffering and violations of law. Whereas ROEs are important, up until recently they have not commonly been used by the Indonesian Army.

Taking into consideration the above mentioned, the topic of ROEs was inserted into the training program. On top of that, one and half days, or two days of a four or five days training was allocated as a workshop on ROEs. Subsequently the title of the training became "IHL and Human Rights Training and Workshop on ROEs". Moreover, a set of ROEs and case studies had been developed for the purpose of these trainings. ${ }^{59}$

The insertion of ROE into the IHL training started around 2008. After some training sessions had been conducted the awareness of the importance of ROEs increased. Several Army units began to apply ROEs in their operational planning and training. In 2010 a workshop on ROEs was conducted at the TNI $\mathrm{HQ}$ and was attended by senior officers from all the main command units of TNI ("Kotama

\footnotetext{
${ }^{57}$ The author is in the opinion that the situation in Aceh qualified as a non-international armed conflict where the IHL and Article 3 of the GC is apply. See, Fadillah Agus, "The Internal Armed Conflict in Indonesia According to the Geneva Conventions 1949 and its Second Additional Protocol 1977 in relation with the Indonesian Criminal Code", Dissertation, Padjadjaran University, Bandung, 2011, pages $223-296$.

${ }^{58}$ Civilian experts and Norwegian Army officers are part of the instructors contributed by NCHR to the program.

${ }^{59}$ Thanks to Lt.Col. Moen Stein of the Norwegian Army who dedicated his time to develop the training tools called "the FRR ROE Exercise". With some modification and adjustment to the command structure as well as strategy, tactic and technicalities of the TNI so the tools is suitable to be used in the Indonesian Army training.
} 
TNI“) covering Army, Navy and Air Force. The workshop resulted in a common understanding of ROE related issues among the participants. As a follow-up of this workshop a series of seminar on ROEs were conducted in TNI HQ and attended by senior officers i.e. Colonels and Lt. Colonels.

The impact can be seen in 2011 and 2012 where TNI HQ issued three set of ROEs, i.e. ROE for the operation in conflict prone areas; ROE for operations in border areas; and ROE on military support to Police operations. In addition, a Guidance Book for Drafting ROE was also issued. The ROEs were issued in the form of the Commander in Chief Regulation ("Peraturan Panglima / Perpang").

FRR was also organized IHL training for the Navy and the Air Force. Even if the trainings for the Navy and the Air Force were not as extensive as those for the Army but the quality was the same. This program also had an operational approach and the instructors were also a mix of military and civilians, both Indonesian nationals and foreigners. ${ }^{60}$

Due to the nature of Naval and Air Force operations, the context being used in the trainings was the international armed conflict Therefore, not so many case studies related to Indonesia were presented during these trainings. However, the operation to release an Indonesian merchant ship hijacked by Somalian pirates was one interesting case study discussed. Moreover, the Royal Australian Navy practice in conducting their tasks as the law enforcement officials at the same time as they were the state defense apparatus was a valuable lesson for the Indonesian Navy officers attending the trainings.

References and written materials on $\mathrm{IHL}$ related to Naval and Air Force operations are limited, and none of them have been available in Bahasa Indonesia. In order to fill the gap, the San Remo Manual on the International Law Applicable in the Armed Conflict at Sea has been translated into bahasa Indonesia. ${ }^{61}$ In addition, with the permission of the International Institute of Humanitarian Law, FRR also translated the IIHL Hand Book on ROEs. These materials are very useful for TNI members in order to deepen their knowledge and understanding on IHL related issues.

\section{G. The Challenges}

Some achievements of the dissemination work was made during the period from 1998 to 2015 i.e. from increased awareness to more tangible effects such as changes to operational approaches and doctrine. However, the said achievements could have been achieved faster if the operational and intelligence officers, and in particular the commanding officers, had been involved in the dissemination session earlier. For instance, a five days IHL training session conducted in 2008 at the Division 2 of KOSTRAD certainly gave a positive and immediate impact to the unit. This was partly due to the fact that the participants at this training were battalion and company commanders. Commanding officers are seemingly more credible and effective than legal officers in conveying the IHL and human rights messages to their units.

\footnotetext{
${ }^{60}$ Most of trainings that organized by FRR for the Navy and Air Force were supported by the Australian government. Australian Navy officers from the Asia Pacific Center for Military Law, as well as from the Australian Air Force were instructors at some of the training sessions.

${ }^{61}$ The Manual is translated by a team consisting of Navy officers and ICRC staff (including the author). The translation book was signed by Chief of Staff of the Navy, Admiral Kent Sondakh.
} 
The Implementation of Article 47 Geneva Convention I to the Military

Moreover, the composition and qualification of the training team is essential in order to achieve the objectives of the training. One ideal team should consist of legal, operational, intelligence and training officers. $^{62}$ Given the size of $\mathrm{TNI}^{63}$ and the territory of the country, there is a need to establish specially designed teams that are tasked with the responsibility of IHL and human rights dissemination within the TNI. This should not be difficult for TNI nowadays as there are several officers from all branches that possess appropriate knowledge on IHL. Whereas much IHL knowledge may be in place, the capability of legal officers to comprehend military strategy, tactics and even battle technic needs to be improved.

Most dissemination session within TNI that the author has observed have been run and lead by legal officers, this also include simulations and field exercise sessions. This may create the misunderstanding that what is learned during dissemination sessions is merely legal issues of little operational relevance. Furthermore, this also creates the misperception expressed by some officers: "forget the tactics during legal training and forget the law during tactical training".

As NIAC is the most likely kind of conflict to occur in Indonesia in the foreseeable future, the training program should also be targeting soldiers at the lower levels i.e. private and sergeants, and in particular infantry soldiers. The program and curriculum should be designed in such a way that it closely resembles conventional warfare ${ }^{64}$ and counter insurgency operations.

The objective of the trainings is to make the soldiers' behavior in the combat battle field compliant with IHL and HR and to make it integrate into the muscles and bones of the soldiers rather than merely stick it in their brains. Therefore the contents and methodology of the trainings should be designed in such a way that the practical aspects are highlighted and the theoretical side of the law is given less prominence.

The issuance of the three standing ROEs mentioned will hopefully positively influence TNI operation in the future. It will become significantly easier for TNI units to develop ROEs required for their operations as standing ROEs and guidance to draft the ROEs now is available. However the knowledge and skills of the commanding, operational as well as legal officers to draft suitable ROEs need to be improved, particularly their skills on drafting ROEs related to NIAC. In this regard TNI needs to have its own military manual on IHL. Such a manual will reflect the TNI's views, policies and perception of IHL related issues. ${ }^{65}$

The awareness and implementation of IHL within the TNI today is far better than it was prior to 1998. To consolidate this development a general corps seminar on IHL and human rights should be organized. Such a seminar should be attended by brigadier generals up to the Chief of Defense and focus on the philosophy and

${ }^{62}$ It would be fine if at the beginning phase the embryo of the team consists of a qualified legal officers which then is complement by other officers from other branches in order to form a solid and comprehensive instructor team.

${ }^{63}$ The members of TNI by 2014 is 314,271 personnel; Ministry of Defense, State Defense Posture, 2014, page 26.

${ }^{64} \mathrm{No}$ need to include in the program, for example, the electronic warfare as this is too complicate for the foot soldiers and less likely to happen in the NIAC in Indonesia.

${ }^{65} \mathrm{An}$ initial draft has been initiated and drafted by FRR. Due to some constraint the work has been postponed. 
values of $\mathrm{IHL}$ and human rights related to the military operations conducted by the TNI.

A remaining challenge is law enforcement in the military realm. The intensive and extensive dissemination work has in fact reduced the amount of violations of law in military operations. Still, occasionally violations occur. This should not be seen abnormal as there is no one that can guarantee a military operation to be conducted without any violations occurred. However, it is important how violations of law are dealt with by the military leader. Can we expect the military justice system to deliver due process of law and independent and reliable handling of cases where violations have taken place? In this regard, an impartial and independent military justice system is required to guarantee a fair trial with no impunity.

A national legislative measures, i.e. to regulate war crimes as enshrined in Article 49 GC I should be done by Indonesia. Neither the Indonesian Penal Code nor the Military Penal Code regulates the war crimes. Even if the country has an impartial and independent justice system but it is difficult to deal with war criminals as the war crime regulations yet to be existed. Fortunately, the war crimes articles are now included in the new draft Penal Code. ${ }^{66}$

Article 47 of GC I should not be read as an independent article. The inspiration of this article came from Article $1 \mathrm{GC}$ which gives an obligation to the High Contracting Parties to respect and ensure the respect of the convention. Further, based on Article 87 of AP I, the commander has the duty to prevent, suppress and to report to competent authorities breaches of the Conventions and of the Protocol. Therefore, dissemination or legal training is one way for commander to fulfil his duty to prevent breaches.

In order to be more effective in fulfilling his duty, based on Article 82 AP I, the commander should be equipped with a legal adviser. Subsequently, TNI required a credible and suitable legal unit which able to provide an appropriate legal advises needed. Therefore, it is recommended that the legal department or unit under the TNI's structure is complement with a unit or section responsible for IHL and/ or operational law. There is no such section in the existing legal unit under the TNI structure so far. Such a section is required at the TNI HQ, the service $\mathrm{HQ}$ down to the combat units at division level. The operational law section will have a central role as legal adviser as enshrined in the Article $82 \mathrm{API}$. However, there is no need to have such section at "Kodam", even though "Kodam" is equal to the division, as the nature of the "Kodam" is a territorial unit and not a combat unit. Whenever a "Kodam" is assigned to function as a combat unit it could then equipped with an ad hoc IHL/operational law unit.

Moreover, the existing position of the legal units within the TNI is under the supervision of the assistant for personnel needs to be reviewed. Such position within the organization provides the legal unit with a non-operational function. ${ }^{67}$ It also leads to limited access for the legal unit to the commander. It would be

\footnotetext{
${ }^{66}$ Book II, Chapter IX, Article 396 - 399 Draft Penal Code 2012. The draft has been sent by the Government to the Parliament and the Parliament is now working on it.

${ }^{67}$ The task and function of the legal unit is very much occupied with judiciary matters, contracts and legal problems related with administrative and personnel issues.
} 
The Implementation of Article 47 Geneva Convention I to the Military

preferable to put the legal unit under the supervision of the assistant of operations, or at least, that the operational law/ IHL section of the legal unit is under the supervision of the assistant of operations. Another option would be to create a new separate operational law unit under the assistant of operation

Article 2 section (4) of the Law No. 34 of 2004 on TNI stipulates that one of the identities of a TNI soldier is as a professional soldier. The requirement for a professional soldier mentioned there, are among others, well trained, well-educated, well-equipped, respect human rights, national law as well as international law that has been ratified by Indonesia. Therefore, in the Indonesian case, Article 47 GC I should be implemented in the form of trainings related to operations where the desired output should be the shaping of professional soldiers who abide by national and international law respectively.

\section{H. Concluding Remarks}

Article 47 of GC I is closely related with articles 1 and 49 of the Geneva Convention I as well as articles 82 and 87 Additional Protocol I. The appropriate ROEs, soldier's behavior in combat and the reliable enforcement mechanism are the indicators that the IHL dissemination program had been succeed. Even though violations are constant and present everywhere, Indonesia can be a good example to highlight situations where IHL has indeed been respected and show that it can have a positive impact.

\section{Bibliography}

\section{Books}

IHL Center of Syiah Kuala University, Banda Aceh and Sam Ratulangi University, Manado, North Sulawesi, Research on the National Implementation on IHL, 2001.
Henckaerts, Jen-Marie and Louise DoswaldBeck, Customary International Humanitarian Law, Vol. I and II, Cambridge University Press, 2005.

Pictet, Jean S., et.al., Commentary I Geneva Convention, International Committee of the Red Cross, Geneva, 1952.

Sandoz, Yves, et.al., Commentary on the Additional Protocols of 8 June 1977 to the Geneva Conventions of 12 August 1949, ICRC - Martinus Nijhoff Publishers, Geneva 1987.

Gill, Terry D., and Dieter Fleck (eds.), The Handbook of the International Law of Military Operations, Oxford University Press, 2011.

\section{Law Instruments}

Declaration on Human Rights 1948.

Geneva Convention 1949 and its Protocols.

Law No. 59 of 1958 concerning Indonesia participating in All Geneva Conventions.

\section{Other Sources}

Fadillah Agus, "The Internal Armed Conflict in Indonesia According to the Geneva Conventions 1949 and its Second Additional Protocol 1977 in relation with the Indonesian Criminal Code", Dissertation, Padjadjaran University, Bandung, 2011.

\section{Legal Documents}

Declaration on Human Rights 1948.

Geneva Convention 1949 and its Protocols.

Law No. 59 of 1958 concerning Indonesia participating in All Geneva Conventions. 